\title{
Negotiating the Balance of Religious Freedom and Equal Rights
}

On a cold December night in Brockton, Massachusetts, nine-year-old Betty Simmons stood alone on a street corner. In a canvas bag over her shoulder, she carried magazines published by the Jehovah's Witnesses containing teachings on biblical prophecies and religious history. Betty held copies to display to passersby, and her bag advertised that the magazines were for sale. ${ }^{1}$

About 20 feet away, Betty's aunt and legal guardian, Sarah Prince, stood engaging in her own street preaching work, as she did regularly. Around 8:45 p.m., a school attendance officer approached Sarah and asked for Betty's name and where she went to school. Sarah refused to provide her niece's name, but admitted she had provided Betty with the magazines to sell. The officer advised her to go home within five minutes, citing previous warnings he had given. Although Sarah complied, she vigorously objected, "This child is exercising her God-given right and her constitutional right to preach the gospel, and no creature has a right to interfere with God's commands."

Under a Massachusetts statute, however, children were forbidden from selling merchandise in public places, and adults who provided children with goods to sell or permitted them to work in violation of the law could be charged with a misdemeanor. Because of Betty's repeated appearances selling religious literature on the streets of Brockton, and Sarah's acknowledgment that it was at her behest, Sarah was convicted and fined for violating the state's child labor laws. 
Over the next three years, Sarah challenged the decision through the courts, arguing that the child labor provision violated Betty's right to religious freedom, Sarah's right to raise her child within her own faith, and both of their rights to freedom from discrimination. Since street preaching and distributing literature were critical aspects of Jehovah's Witnesses's religious practice, she argued, the restriction on children selling goods in the street amounted to discrimination against members of the faith. During trial, Betty testified that she believed failing to spread Jehovah's Witnesses's teachings would condemn her "to everlasting destruction at Armageddon." ${ }^{3}$

When the case reached the Supreme Court, however, Justice Wiley Rutledge clarified that freedom of religion, although central to the constitution's First Amendment, is not absolute. In particular, he argued, "The right to practice religion freely does not include the right to expose the community or the child to communicable disease or the latter to ill-health or death." 4 Further, although Betty had a right to religious freedom, different standards could validly apply to children and adults, given the "interests of society to protect the welfare of children," and democracy's reliance upon "the healthy, well rounded growth of young people into full maturity as citizens." 5 While adults were free to sell religious materials in the streets, even during severe cold weather, the child labor law was a valid exercise of Massachusetts's authority to protect against the "crippling effects of child employment." ${ }^{\circ}$

Turning to Sarah's argument about her right to raise her child in her faith, the Court reasoned that despite the government's obligation to respect private family life, "the family itself is not beyond regulation in the public interest." 7 Notably, the Court did not argue that Sarah could not provide Betty with the religious education of her choosing; she simply could not compel Betty to engage in religious practices that violated the law. Finally, addressing Sarah's equal protection claim, the Court concluded that as a generally applicable law that treated children of all faiths the same, the child labor legislation was not discriminatory against Jehovah's Witnesses.

\section{PERSISTING QUESTIONS-AND MOVES TOWARD \\ GLOBAL CONSENSUS}

Prince v. Massachusetts was decided 75 years ago, but its most fundamental issues remain relevant across countries. In the United States, the decision continues to serve as a critical precedent in cases where religious freedom is pitted against public health or children's safety. ${ }^{8}$ Globally, Prince exemplifies some common questions that emerge when tensions arise between the exercise of religion and other fundamental rights and state interests. Under what conditions can the government restrict religious practice?

In the decades since Prince, heated debates about religion's ideal role in society-and in constitutions-have persisted, though important moves toward consensus have occurred in key areas. 
International agreements have addressed rights to equality across religions. Beginning with the Universal Declaration of Human Rights (UDHR), countries from all regions collectively established a comprehensive set of principles articulating important protections for equal rights on the basis of religion. The International Covenant on Civil and Political Rights (ICCPR), adopted in 1966, and the Declaration on Elimination of All Forms of Intolerance and of Discrimination Based on Religion or Belief, adopted in 1981, further clarified these goals and responsibilities.

These agreements also express the global consensus that, while important and widely valued across societies, the ability to practice one's religion is not unqualified: it can be curtailed in some circumstances, such as for public health and the protection of others' fundamental rights and freedoms, including their rights to equality. At the same time, individuals of all religions, beliefs, and nonbeliefs must be protected from discrimination and persecution, whether in countries with religious governments, secular governments, or increasing religious diversity.

Achieving broad global agreement on key principles has been a remarkable step. But to what extent have they translated into practice?

\section{EQUAL RIGHTS ON THE BASIS OF RELIGION: WHAT IS THE CHALLENGE?}

In some ways, protecting against religious discrimination is similar to protecting against discrimination on the basis of race/ethnicity, gender, or other aspects of identity. Constitutional nondiscrimination clauses that include religion can ensure that members of religious minorities have the same rights to access education, work, participate in government, and lead full lives as members of the majority.

Yet a more challenging issue for national constitutions is that, more than other aspects of identity, an individual's religion may prescribe a set of rules to live by. Religious laws and practices related to family, marriage, child-bearing, death, property, and other realms of life may intersect with areas covered by the state.

Moreover, historical traditions of a wide range of religions have come into conflict with the equal rights of groups both within and outside these religions. Inequalities remain embedded in some religious legal systems; disparities in property rights ${ }^{9}$ and the criminalization of groups ${ }^{10}$ present just two examples. Yet, for most religions, there are also adherents who believe the religion can be practiced while respecting the equal rights of all.

\section{International Agreements on Respecting Religious Freedom While Guaranteeing Human Rights to All}

While freedom of religion and separation of religion and state are ideas that have a long global history, dating back at least to ancient Greece, much of the progress is centuries old. ${ }^{11}$ In 1598, the Edict of Nantes newly granted rights to Protestants in 
predominantly Catholic France, opening the door to religious tolerance and secularism. In the United States, religious freedom was foundational to the American Revolution, and as Virginia's governor, Thomas Jefferson drafted a bill to grant "legal equality for citizens of all religions-including those of no religion" within the state. ${ }^{12}$ In the early twentieth century, Kemal Ataturk's deep commitment to secular government marked the end of the Ottoman Empire, and the beginning of a staunchly secular Turkey. ${ }^{13}$

Yet these developments coincided with a long history of religious persecution by leaders and states. In ancient Rome, Christians suffered several centuries of persecution until the emperor Constantine converted to Christianity in $312 \mathrm{AD}$; after his infamous vision of the cross with the words "In this sign you will conquer," Constantine went on to subject pagans to the same relentless treatment, partly through discriminatory laws. ${ }^{14}$ Beginning in the fifteenth century, Spain's monarchy expelled hundreds of thousands of Jews from the country, and persecuted thousands of "New Christians" suspected of continuing to practice Judaism despite being forced to convert. ${ }^{15}$ Throughout the nineteenth century, national struggles against the Ottoman Empire led to large-scale violence against Muslims in Greece, ${ }^{16}$ Serbia, ${ }^{17}$ and elsewhere. Numerous other countries offer similar examples. It was religious persecution at its worst-genocide of Jews by the Germans in World War II-that led to global commitments to protect all human rights.

Both the UDHR and the ICCPR, as well as subsequent agreements, guarantee freedom of religion. Specifically, the UDHR prohibits discrimination on the basis of religion, and further proclaims: "Everyone has the right to freedom of thought, conscience and religion; this right includes freedom to change his religion or belief, and freedom, either alone or in community with others and in public or private, to manifest his religion or belief in teaching, practice, worship and observance." These agreements also establish that "freedom of religion" applies equally to the freedom to believe and the freedom to not believe. According to Article 18 of the ICCPR, "[n]o one shall be subject to coercion which would impair his freedom to have or to adopt a religion or belief of his choice." The U.N. Human Rights Committee has clarified that Article 18 "protects theistic, non-theistic and atheistic beliefs, as well as the right not to profess any religion or belief," and that " $[\mathrm{t}] \mathrm{he}$ terms 'belief' and 'religion' are to be broadly construed." ${ }^{18}$ In practice, this means that "freedom of religion" encompasses not only the right to hold and observe beliefs of one's choice, but also the rights to freely change or denounce one's religion or beliefs.

At the same time, these documents protect the equal rights of all. The UDHR designated equal rights as the highest priority, even in cases of conflict with other rights, by clearly stating that "[r]ecognition of the inherent dignity and of the equal and inalienable rights of all members of the human family is the foundation of freedom, justice and peace in the world." Similarly, the U.N. has specified that the ICCPR, an enforceable treaty, cannot be used to "sanction discrimination 
against any group of persons," 19 and that Article 18 in particular "may not be relied upon to justify discrimination against women by reference to freedom of thought, conscience and religion." ${ }^{20}$

The international agreements embodying these values have been widely signed and ratified by countries around the world. The 171 U.N. member states that have ratified the ICCPR comprise all countries in Europe and Central Asia, 96\% of those in sub-Saharan Africa, $89 \%$ of those in the Americas, $88 \%$ of those in South Asia, $84 \%$ of those in the Middle East and North Africa, and $60 \%$ of those in East Asia and the Pacific.

Freedom of religion is divided into beliefs and practices. There are no restrictions on beliefs. More complex questions emerge around religiously motivated actions. Practices can be subject to limitations that are "prescribed by law and are necessary to protect public safety, order, health, or morals or the fundamental rights and freedoms of others," including their fundamental rights to equality. ${ }^{21}$

Historically and still today, religion has been invoked or interpreted by some in ways to rationalize and excuse unequal treatment. For example, colonialism and slavery, among other large-scale denials of fundamental human rights, have been justified on religious grounds at various points in history. So, too, have mass killings.

Like the UDHR, ICCPR, and International Covenant on Economic, Social and Cultural Rights, the Declaration on the Rights of Persons Belonging to National or Ethnic, Religious and Linguistic Minorities protects equal human rights. The declaration makes the state responsible for ensuring that while groups covered by the declaration can make decisions relevant to the group, those groups cannot "discriminate in any way against any person on the basis of his/her group identity and must take action to secure their equal treatment by and before the law." The declaration then proceeds to discuss with clarity how actions related to the group identity must accord with international standards of treating all people equally. ${ }^{22}$

Regional bodies have independently developed principles that likewise honor equal treatment of all religions while simultaneously requiring that religious practice respects all people's equal rights. For example, the African Charter on Human and Peoples' Rights, ratified by all the continent's countries but one, ${ }^{23}$ protects freedom of religious practice while explicitly prohibiting discrimination on the basis of sex, race, social origin, and other characteristics. Further, the Maputo Protocol, an add-on to the charter addressing women's rights that has been ratified by 36 African countries and signed by another $15,{ }^{24}$ specifically calls for all countries to "include in their national constitutions and other legislative instruments . . the principle of equality between women and men and ensure its effective application." ${ }^{25}$ In guidance detailing the protocol's commitments, the African Commission made clear that countries had a duty to ensure religious beliefs did not undermine women's right to health. ${ }^{26}$ 


\section{The State of the World's Constitutions}

Three core principles, grounded in international agreements, can help ensure that governments equally support the dignity and fundamental rights of all, regardless of religion, belief, or nonbelief. The first is to ensure that the government does not privilege one religion over other religions or beliefs. The most straightforward approach to doing so is a commitment to secular government. Second, countries must ensure that there is no religious discrimination by public or private institutions, to the extent the constitution covers the private sector. Third, governments must protect freedom of belief for all in their borders, and protect freedom of practice up to the point where it infringes on the fundamental rights of others.

Like equal rights, freedom of religion and separation of religion and state are principles that societies around the world have long deemed valuable, including within their constitutional documents. The Constitution of Medina, believed to have been drafted by the Islamic prophet Mohammad in the early seventh century, explicitly protected freedom of religion for all within the city walls. ${ }^{27}$ The Magna Carta, drafted in 1215, declared "that the English church shall be free," interpreted by some to provide an early guarantee of separation between religion and state. ${ }^{28}$ The Great Law of Peace, considered the oral constitution of the Iroquois confederacy that predated European colonization of North America, included freedom of religion as a fundamental principle. ${ }^{29}$ In the United States, freedom of religion and separation of religion and state were understood to be so foundational that these principles were enshrined in the constitution's first amendment in 1789. Yet in the modern human rights era, how do constitutions protect religious freedom while ensuring equality?

In this chapter, we seek to understand how constitutions address equality across people with different beliefs, ensure equality between believers and nonbelievers, and protect religious freedom without allowing infringements of other rights. To identify the full range of approaches, we comprehensively examined references to religion and belief throughout each constitution's text. As we will explore, constitutions often contain conflicting provisions with regard to religion. For example, some guarantee equal rights regardless of religion, but nevertheless prioritize a single religion elsewhere in the text. Others proclaim their countries secular, but give special recognition to a particular religion legally or symbolically.

Our analysis proceeds in three in-depth sections. In the first, we look at the constitutions that come closest to guaranteeing equal rights regardless of religion or belief by fully enshrining the principles outlined above. In the second, we examine those constitutions with provisions explicitly limiting rights based on religion or establishing a role for religion in governance. Third, we analyze those constitutions that do not formally treat religion as a source of law, but do recognize a particular religious heritage or tradition, or favor religion generally, thus failing to 
treat all religions and beliefs equally. Within each section, we explore the diversity of constitutional choices countries have made, while drawing on case studies to understand how these choices may matter.

By contrast to constitutional protections of equality on other grounds, equal rights on the basis of religion cannot be largely measured by examining nondiscrimination provisions alone. Our goal in this chapter is instead to provide an overview of the wide-ranging constitutional approaches to this important issue, and to highlight the contradictions within constitutional texts that preclude their straightforward categorization.

\section{HOW CONSTITUTIONS CAN GUARANTEE EQUAL RIGHTS AND EQUAL TREATMENT ACROSS RELIGIONS}

Generally, provisions governing religious life fall into those addressing the rights of the individual, and those addressing religion's role in the public sphere. Fully protecting equality requires addressing both elements.

Various pathways allow for fully protecting equal rights, regardless of religion, belief, or nonbelief, while simultaneously upholding other fundamental rights. For example, a country could adopt a "multidenominational" or "multicultural" approach that supports all religions equally. This approach typically welcomes religious expression in the public sphere by people of all faiths, and may provide tax exemptions or other financial support to religious groups. At the same time, to adequately protect equality and dignity for all and avoid privileging religiosity over nonbelief, this country would protect the rights of nonreligious people and ensure that nonreligious organizations with similar civic, educational, or charitable purposes are eligible for all the same benefits as the religious groups. Finally, this country would ensure that the public or private exercise of religious beliefs does not violate the rights of others.

A second possible approach is to completely separate religion and state. Under this approach, religious groups receive no privileges or special recognition from the government, and religious practice is largely confined to the private sphere rather than supported by public resources or institutions. This country would also clearly protect freedom of religion, limiting religious practice only where it affects others' fundamental rights. Finally, this country would guarantee nondiscrimination and equal rights regardless of whether people have any belief in religion.

Currently, just $7 \%$ of constitutions cover all elements described above: nondiscrimination; freedom of religion, including freedom to not believe; limitations on religious practice to protect people's rights; and no implicit or explicit state privileging of religion (Table 1). For example, Slovenia's constitution provides: 


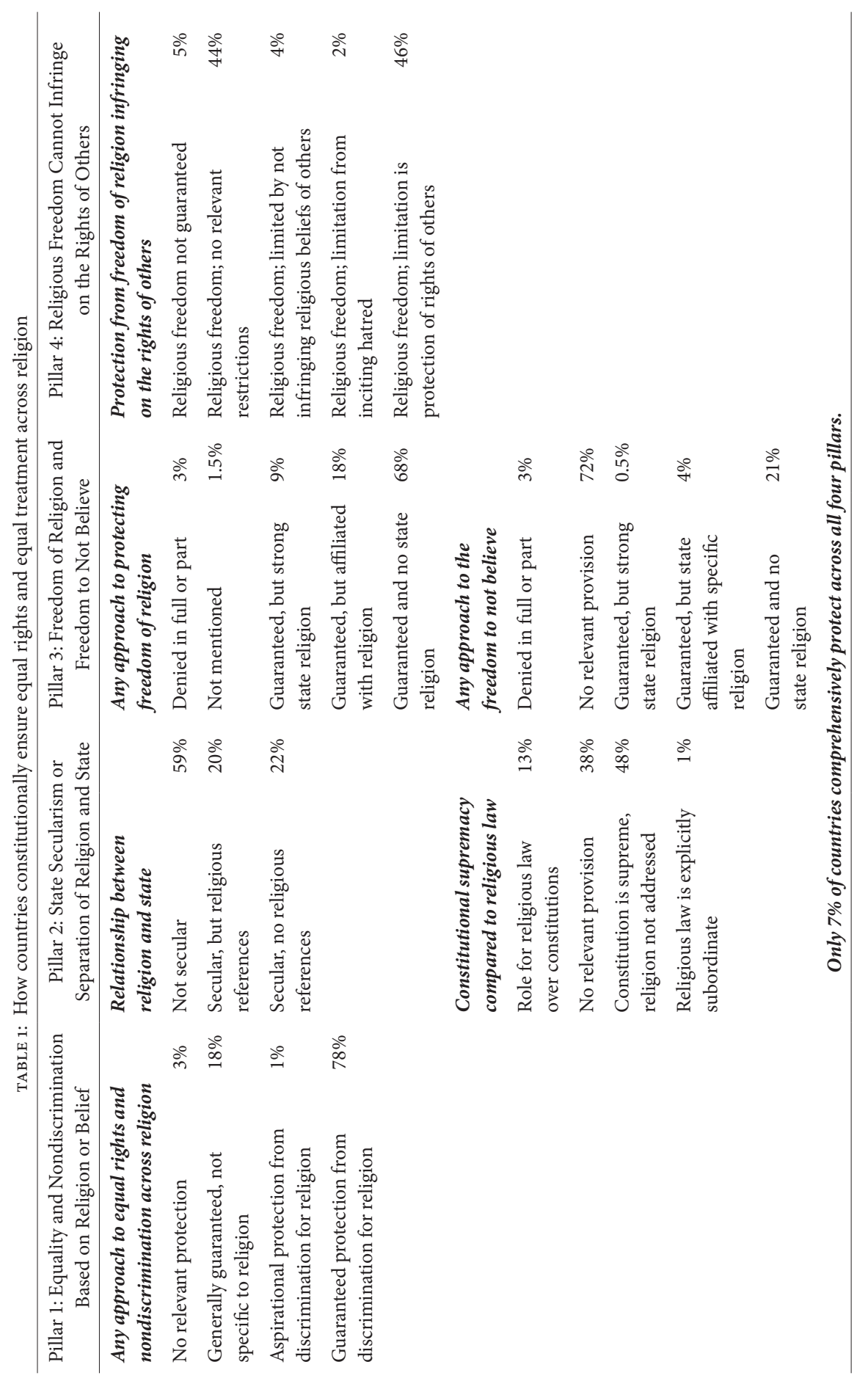


- Article 7: "The state and religious communities shall be separate. Religious communities shall enjoy equal rights; they shall pursue their activities freely."

- Article 14: "In Slovenia everyone shall be guaranteed equal human rights and fundamental freedoms irrespective of ... religion, political or other conviction."

- Article 15: "Human rights and fundamental freedoms shall be limited only by the rights of others and in such cases as are provided by this Constitution."

- Article 41: "Religious and other beliefs may be freely professed in private and public life." ${ }^{30}$

Likewise, Nicaragua covers these elements through four separate articles:

- Article 14: "The State has no official religion."

- Article 27: "There shall be no discrimination based on birth, nationality, political belief, race, gender, language, religion, opinion, origin, economic position or social condition."

- Article 28: "Everyone has the right to freedom of conscience and thought and to profess or not profess a religion."

- Article 69: "All persons, either individually or in a group, have the right to manifest their religious beliefs in public or private, through worship, practices and teachings. No one may evade obedience to the law or impede others from exercising their rights and fulfilling their duties by invoking religious beliefs or dispositions."31

Burkina Faso's constitution addresses each element as follows:

- Article 1: "Discrimination of all sorts, notably those founded on race, ethnicity, region, color, sex, language, religion, caste, political opinions, wealth and birth, are prohibited."

- Article 7: "The freedom of belief, of non-belief, of conscience, of religious opinion, [of] philosophy, of exercise of belief ... are guaranteed by this Constitution, under reserve of respect for the law, for public order, for good morals and for the human person."

- Article 31: "Burkina Faso is a democratic, unitary and secular State." ${ }^{2}$

As Table 1 illustrates, some types of provisions, such as nondiscrimination on the basis of religion, are widespread; protections for the right to nonbelief are less common. Examining each element individually provides further insights into why these provisions matter and where there are opportunities for strengthening protections for equality.

\section{Nondiscrimination on the Basis of Religion}

As with other areas of equal rights, ensuring nondiscrimination on the basis of religion is foundational. Evidence shows that religious discrimination continues to limit access to basic opportunities and institutions, while having wide-ranging health impacts. For example, in Denmark, which lacks any protections against discrimination in its constitution, a 2017 survey found that over one in five Muslims 


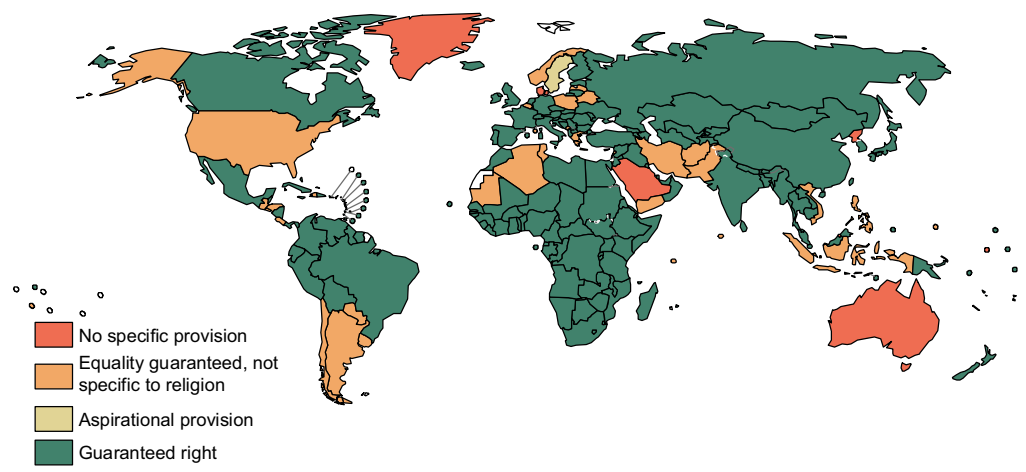

MAP 12. Does the constitution explicitly guarantee equality or nondiscrimination across religion?

had experienced discrimination in the preceding five years in employment, education (as a parent/guardian), or housing. ${ }^{33}$ In Greece, where the constitution recognizes the Greek Orthodox Church as the "prevailing religion" and the vast majority of citizens identify as Orthodox, research has shown that members of minority faiths, such as Pentecostals and Jehovah's Witnesses, consistently receive fewer callbacks and lower initial salary offers. ${ }^{34}$ In many countries, discrimination on the basis of religion (or perceived religion) intersects with discrimination on the basis of race/ethnicity and nationality. ${ }^{35}$

Similarly, violence targeting members of particular religious groups, or those perceived to be members of those groups, remains commonplace. In 2017, 1,749 people were victims of antireligious hate crimes in the United States; over half were targeted for being Jewish, and nearly one-fifth for being Muslim. ${ }^{36}$ Moreover, these figures likely underestimate the scope of the problem. In a 2013 survey spanning Europe, $64 \%$ of respondents who reported having experienced anti-Semitic physical violence or threats of violence said they had not contacted the police about the most serious incident. ${ }^{37}$

Globally, $78 \%$ of constitutions explicitly guarantee equality and nondiscrimination based on religion or belief (Map 12). For example, Peru's constitution states: "Every person has the right ... [t]o equality before the law. No person shall be discriminated against on the basis of . . . religion, opinion, ... or any other distinguishing feature." 38

These provisions appear more frequently in more recently enacted constitutions: half $(56 \%)$ of those adopted before 1970 explicitly guarantee equal rights regardless of religion, compared to $92 \%$ of those adopted in $2010-$ 17 (see Figure 7).

As with provisions banning discrimination on other grounds, constitutional protections against religious discrimination can play a critical role in ensuring a given policy or practice does not target a specific group. A recent case from Germany provides one example. 


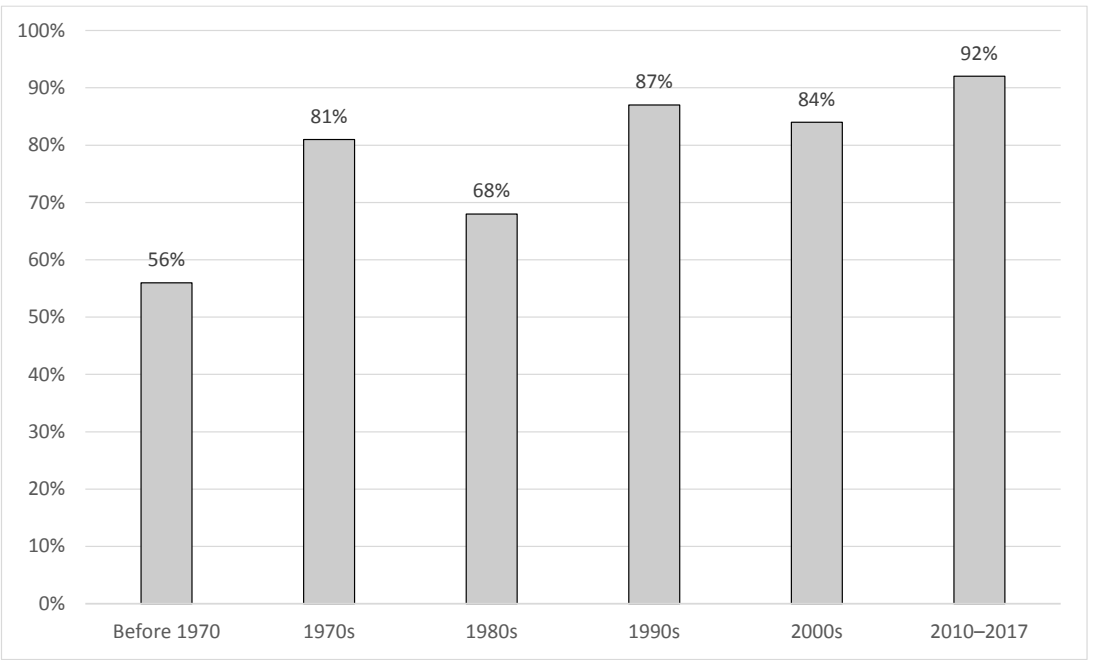

FIGURE 7. Explicit constitutional guarantee of equality or nondiscrimination across religion by year of constitutional adoption

In 2015, two teachers in North Rhine-Westphalia suddenly found themselves facing unemployment-not because of their performance or budget issues, but because of their attire. Both teachers were Muslim women who wore the Islamic headscarf, which they understood as a requirement of their faith. Yet under a new state law, "political, religious, or other ideological expressions by public school teachers" were prohibited if they had "the potential to endanger or disturb state neutrality or the peace at school." ${ }^{39}$

The law made an explicit exception for the expression of Christian traditions. However, the Islamic headscarf was quickly deemed a violation. Both teachers received warnings from their employers after the law went into effect. One of them, a social science teacher, offered to instead wear a cap and matching turtleneck, but school authorities found that this substitute could still be perceived as a "manifestation of Islamic faith," and was thus prohibited. The second, a Turkish language teacher who simply refused to comply with the ban, was fired.

In an effort to keep their jobs, the women took their case to court. In a 6-2 decision, the German Constitutional Court upheld the law, but found that it had been incorrectly applied. As long as teachers' visible expressions of their faith were not accompanied by proselytizing, the Court found, they did not undermine the state's religious neutrality or infringe upon students' right to education free from religious indoctrination. ${ }^{\circ 0}$ Additionally, the Court ruled that the law's exemption for Christian symbols and traditions was discriminatory and consequently invalid. ${ }^{41}$ Finally, the Court noted that since women alone wore the headscarf for religious reasons, its prohibition would in practice discriminate against women in the workplace. ${ }^{42}$ 
The issue of restrictions on religious apparel has raised constitutional questions in many countries, and courts have reached different conclusions sometimes because of different decision makers and at other times because the questions relating to equal treatment and impact on both religious practice and other human rights differ. ${ }^{43} \mathrm{~A}$ full review of these cases is beyond the scope of this chapter, and the topic as a whole raises many complex considerations. Sometimes, however, the matter before the court is relatively straightforward. The law in Germany, which banned teachers from wearing attire associated with a minority religion while specifically allowing teachers to wear Christian symbols, provides a clear-cut example of religious discrimination, which the constitution, and specifically its guarantee that "no one may be placed at a disadvantage or favoured because of his or her faith or religious views," was well positioned to address. ${ }^{44}$

\section{No Role for Religion in Governance or Support for Particular Faiths}

As the German Constitutional Court's reasoning suggests, one important component of equality across religions is ensuring that the government does not implicitly or explicitly support one religion over others, or over nonbelief. The same principles and concerns apply to constitutional texts themselves. In some countries, the constitution explicitly supports a specific religion, which may also be a source of law. In others, the constitution articulates a commitment to religious neutrality, but also contains religious references indicating a preference for a specific set of beliefs. In either case, the constitutional language is at odds with full equal rights and treatment of people of all religions and beliefs.

In total, $41 \%$ of constitutions establish state secularism or separation of religion and state. For example, France's constitution provides: "France shall be an indivisible, secular, democratic and social Republic." ${ }^{45}$ However, nearly half of these constitutions nevertheless include religious references or specify a role for religion.

Among the $22 \%$ of constitutions that include an unconditional commitment to secularism, a handful explicitly place limitations on the relationship between government and religion. For example, Japan's constitution states that "[n]o religious organization shall receive any privileges from the State, nor exercise any political authority. . . . The State and its organs shall refrain from religious education or any other religious activity," and further clarifies that "[n]o public money or other property shall be expended or appropriated for the use, benefit or maintenance of any religious institution or association." 46

\section{Freedom of Religion-and Freedom to Not Believe}

Despite some overlap with protections against religious discrimination, freedom of religion more specifically guarantees that the state will not interfere with individuals' beliefs. The freedom to hold beliefs of one's choosing, or to hold no religious beliefs, is central to broader protections for civil and political rights, and to building societies that allow for diversity of thought and opinion. Freedom of religion should 


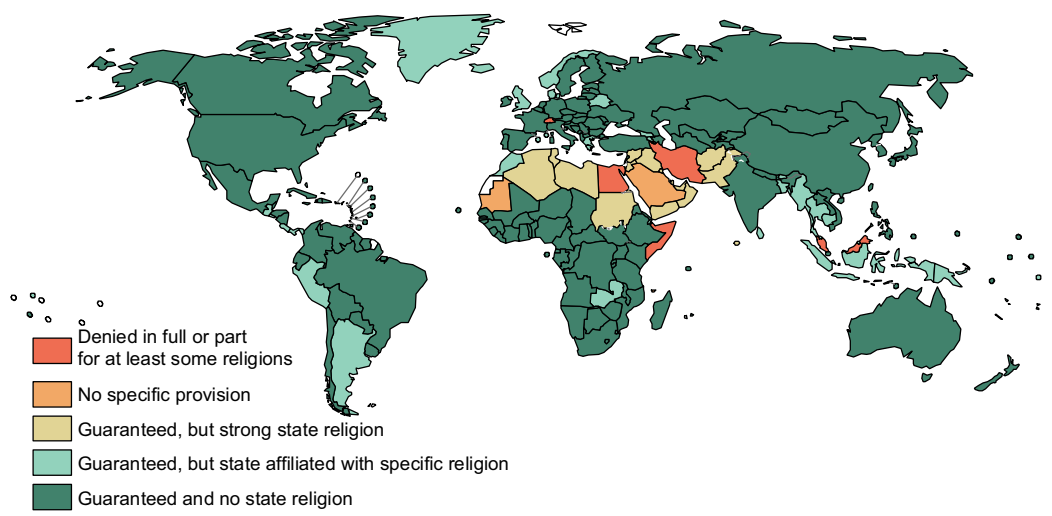

MAP 13. Does the constitution take an explicit approach to protecting freedom of religion?

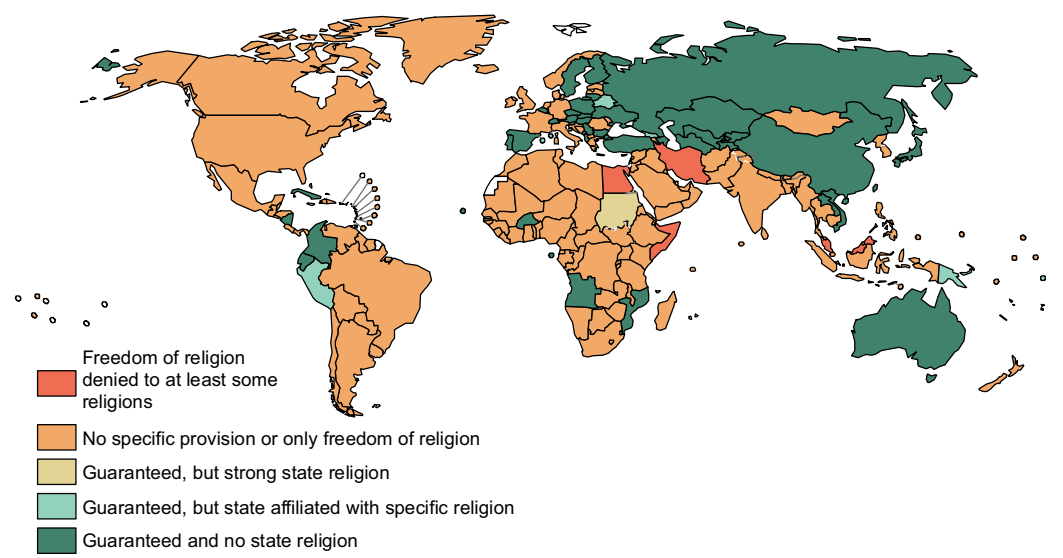

MAP 14. Does the constitution explicitly protect freedom to not believe in religion?

also include the freedom to change or denounce a religion. These protections are critical everywhere, but especially in countries that maintain an official state religion or where minority religions or the nonreligious have historically faced persecution.

Today, the vast majority of national constitutions- $95 \%$-take some approach to protecting freedom of religion or belief (Map 13). However, $18 \%$ of constitutions state that they guarantee freedom of religion, but are affiliated with a specific religion. Similarly, $9 \%$ of constitutions have language guaranteeing freedom of religion, but have a strong state religion that governs public and/or private life, which may directly limit full expression of freedom of religion for religious minorities.

Further, only $25 \%$ of constitutions explicitly protect the freedom to not believe, practice, or disclose one's religion (Map 14). For example, Russia's constitution provides: "Everyone shall be guaranteed freedom of conscience and religion, 
including the right to profess individually or collectively any religion or not to profess any religion, and freely to choose, possess and disseminate religious and other convictions and act in accordance with them." ${ }^{77}$ Similarly, Japan's constitution establishes that "[n]o person shall be compelled to take part in any religious act, celebration, rite or practice." 48

Only $23 \%$ of constitutions protect the right to change religion.

\section{Protections for the Rights of Others}

Constitutional provisions on freedom of religion take a range of approaches to distinguishing between belief and practice, and particularly whether restrictions on religious practice to protect others' fundamental human rights are permissible. Religious conduct is protected from government interference, but subject to limitations: again, as the ICCPR establishes, countries can limit religiously motivated actions where such restrictions are "prescribed by law and are necessary to protect public safety, order, health, or morals or the fundamental rights and freedoms of others." 49 These limitations are designed to provide protection against religious practices that have discriminatory impacts or jeopardize equal access to education, healthcare, employment, and other universal human rights. Restrictions intended to protect the fundamental rights of others are both consistent with the ICCPR and essential to maintaining the balance between freedom of religion and equality.

Some constitutions make clear that religious conduct can be limited, even if belief is unqualified. For example, Greece's constitution states: "Freedom of religious conscience is inviolable. ... All known religions shall be free and their rites of worship shall be performed unhindered and under the protection of the law. The practice of rites of worship is not allowed to offend public order or the good usages." ${ }_{50}$ However, others leave this distinction more open-ended, which may engender case law challenging what "freedom of religion" truly encompasses. The United States, for instance, simply provides: "Congress shall make no law respecting an establishment of religion, or prohibiting the free exercise thereof." ${ }^{11}$ In one of its earliest "free exercise" cases, the U.S. Supreme Court upheld a federal law banning polygamy, finding that "[1]aws are made for the government of actions, and while they cannot interfere with mere religious belief and opinions, they may with practices." ${ }^{2}$

Only $46 \%$ of constitutions explicitly prevent freedom of religion from infringing on the rights and freedoms of others, including their right to equality (Map 15). For example, Antigua and Barbuda's constitution states that like other rights, freedom of religion is "subject to such limitations ... to ensure that the enjoyment of the said rights and freedoms by any individual does not prejudice the rights and freedoms of others or the public interest." 53 Much smaller numbers include language specifically prohibiting the use of religion to incite hatred or create social divisions, or allowing limitations on freedom of religion only to protect others' religious beliefs. 


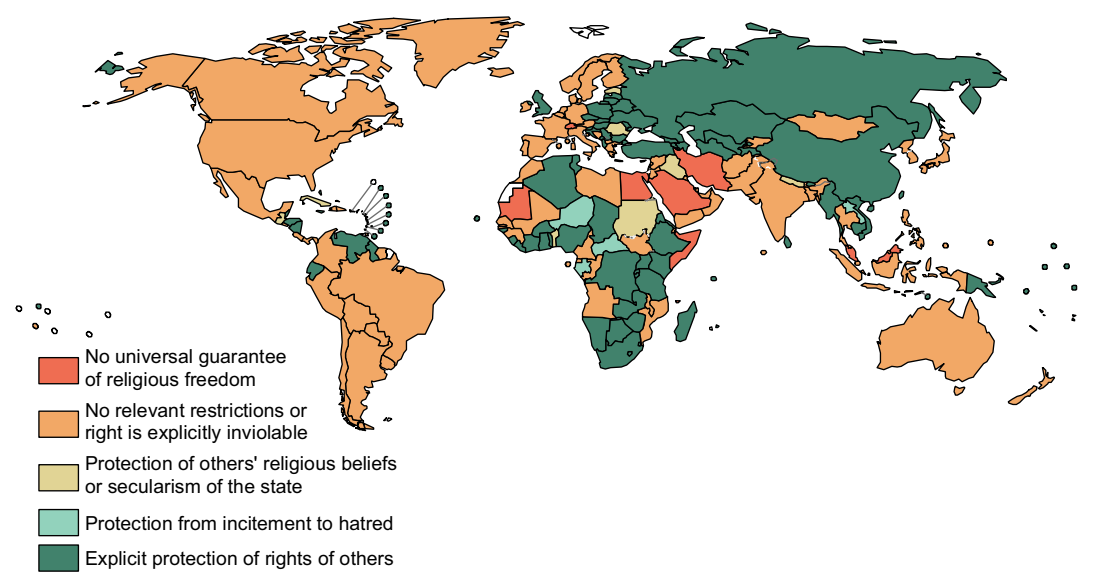

MAP 15. Does the constitution explicitly protect freedom of religion from infringing on the rights of others?

While important restrictions, these narrowly worded provisions offer little protection against religious acts that violate fundamental rights more broadly.

\section{HOW COUNTRIES CAN BE REPRESSIVE OF RELIGIOUS PRACTICE AND EQUAL RIGHTS}

By contrast to the approaches above, some countries' constitutions clearly privilege one religion, or fail to provide essential safeguards for equality and dignity across religions. In these countries, the presence of even one provision explored in this section creates a significant barrier to full equality. At the same time, the severity of the risk to rights varies markedly: a number of countries include a range of elements that restrict freedom of religion simultaneously.

Altogether, $16 \%$ of constitutions include provisions limiting rights for minority religions. In some countries, freedom of religion is protected for the majority religion, but minority faiths and nonbelievers face restrictions. Countries' approaches to religion can also be discriminatory if they impose a specific set of religious beliefs on the population. Some countries apply the law of a designated religion directly through their constitutions; others require the top positions in government to be held by adherents of a specific religion. Similarly, some constitutions require that any laws passed in the country be consistent with religious law or principles-essentially elevating the religion to constitutional status. Finally, some constitutions allow religious law to supersede constitutional provisions either overall or in areas with clear implications for equality, such as family law.

Importantly, even if countries clearly privilege a specific religion in the law, this does not mean that other protections of individual rights are unimportant. 
Explicit protections of the equal rights of women and other groups, for example, can provide tools for challenging discriminatory interpretations of religious law. Further, as demonstrated by a case from Malaysia detailed later in this chapter, protections for freedom of religion have made a difference even in countries with a religious government. However, this case also underscores the limits of freedom of religion alone, and the challenges to effectively practicing one's faith within a broader legal context that privileges a single religion.

\section{Constitutions That Allow Religion to Govern or Take Precedence over Equal Rights}

One way that countries express a clear preference for one religion over others is by designating a state religion. Some countries' constitutions specify that religious law governs public or private life, while others designate a particular religion as historically or culturally significant. While this latter approach may not carry explicit legal implications, it normatively privileges one religion in a way that would be unimaginable in application to race/ethnicity in the twenty-first century. Both of these approaches are inconsistent with a full commitment to equality. However, those countries where religion is the basis of governance, or is allowed to take precedence over constitutional equal rights, pose the graver threat to equality both for people of different faiths and for groups the religion discriminates against.

\section{Religion Governs Public Life}

Altogether, in $10 \%$ of countries, religion governs public life by requiring the executive to be a member of a specific religion and/or having religious law govern public as well as family life (see Map 16). In the Middle East and North Africa, 74\% of countries provide a role for religious law in governance, more than any other region. For example, Kuwait's constitution provides: "The religion of the State is Islam, and the Islamic Sharia shall be a main source of legislation." ${ }^{4}$ Further, many of these countries lack full protections for equal rights on the basis of gender, sexual orientation, and gender identity, which are common bases of discrimination in religious law. The combination of elevating religion to have legal authority and failing to protect all core aspects of equality poses significant risks to the rights of large populations.

\section{Religion Governs Family Life}

Religion governs family but not public life in an additional two constitutions that are affiliated with, or under the jurisdiction of, a specific religion. These include countries that establish religious family law courts. For example, Jordan's constitution establishes that "Islam is the religion of the state" and stipulates that Sharia Courts have exclusive jurisdiction in "matters of personal status of Muslims." 55 This approach differs from that of countries that have no state religion but are willing 


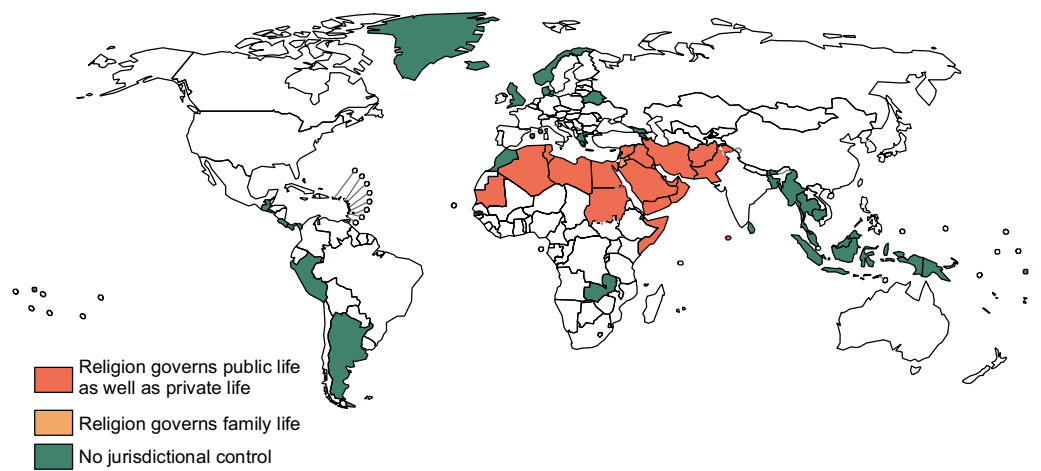

MAP 16. What is the constitutional role of religion in countries where the state is affiliated or under the jurisdictional control of a specific religion?

to recognize religious law in family matters, while requiring conformance with the constitution; the example of South Africa's approach is discussed toward the end of this chapter. By contrast, in countries where religious law governs family life automatically, many people have no say in whether they are bound by religious law with respect to marriage, inheritance, and other issues.

\section{Religious Law Can Supersede Constitution, or Laws Cannot Contradict Religion}

Third, $4 \%$ of countries specify that religious law can prevail over some or all constitutional provisions. In Iran, Saudi Arabia, and Somalia, religious law can supersede the constitution in its entirety. For example, Saudi Arabia's constitution states: "The authority of the regime is derived from the holy qur'an and the prophet's sunnah which rule over this [the constitution] and all other state laws." ${ }_{56}$

In Ethiopia, Kenya, Malaysia, and the Maldives, religious law may prevail over constitutional provisions related to personal law, discrimination, or fundamental rights and freedoms. For example, Ethiopia's constitution states: “This Constitution shall not preclude the adjudication of disputes relating to personal and family laws in accordance with religious or customary laws." ${ }^{57}$ In the Gambia, religious law is generally subordinate to the constitution, but can prevail over discrimination and personal law.

Finally, $5 \%$ of constitutions state that legislation cannot contradict religious law. For example, Afghanistan's constitution states: "No law shall contravene the tenets and provisions of the holy religion of Islam in Afghanistan." ${ }^{8}$

\section{The Risks for Equality of Making Religious Law Supreme}

Notably, even newer constitutions have tended to retain provisions making religious law supreme. Some scholars argue that this trend is not greatly concerning because constitutions with "Islamic supremacy clauses," such as that of Afghanistan, often also 
include relatively substantial protections for civil or political rights, possibly reflecting the role of political coalitions and compromises in their drafting. ${ }^{59}$ However, under Islamic supremacy clauses, these broader rights may fully extend only to a minority of the population. For example, if courts interpret these clauses to allow prohibitions on same-sex relationships and restrictions on women's movement, general constitutional guarantees of freedom of association do not truly apply to all. Likewise, if courts decide that Islamic supremacy clauses allow for preferential treatment of men in inheritance, constitutional guarantees of gender equality are incomplete.

These are not just hypothetical situations. For example, the Maldives's 2008 constitution includes extensive protections of fundamental rights, equality, and the right to privacy, but the country's 2014 penal code nevertheless criminalized homosexuality. ${ }^{60}$ The legislation's stated purpose was "to establish a system of prohibitions and penalties to deal with conduct that unjustifiably and inexcusably causes or threatens harm to those individual or public interests entitled to legal protection, including Islam." This justification aligns with the constitution's state religion provision, which establishes that Islam is a basis of law and that "[n]o law contrary to any tenet of Islam shall be enacted in the Maldives." ${ }^{\prime \prime}$

Importantly, religion is not inherently at odds with equal rights, which arose in many different belief systems, philosophies, and religions around the world. ${ }^{62}$ In fact, many cases of advocacy for greater equality have been partly based on religious beliefs. In Morocco, Muslim women's groups have led efforts to reform discriminatory laws by invoking Islamic principles. ${ }^{63}$ In Southeast Asia, Buddhists led movements for democracy and equal human rights beginning in the 1980 os. ${ }^{64}$ And the U.S. civil rights movement was deeply informed by the faith-infused rhetoric of Dr. Martin Luther King, Jr., an ordained minister, and supported by Christians, Jews, and humanists, among others. ${ }^{65}$ Yet, given the wide-ranging interpretations of doctrine and the history of discrimination, constitutional protections are essential to ensure every person's equal rights are respected.

\section{Constitutions That Limit Freedom of Religion for Specific Groups}

A fourth way that constitutions infringe on equality is by establishing discriminatory standards for religious expression. Some constitutions explicitly limit freedom of religion for particular groups. These provisions range in severity from those completely limiting certain groups' free exercise of religion to those sending exclusionary messages by targeting aspects of religious exercise.

\section{Broad Restrictions on Practice by Religious Minorities}

In some countries, discriminatory limits on freedom of religion take form as broad prohibitions on religious practice. For example, Iran's constitution provides: "Zoroastrian, Jewish, and Christian Iranians are the only recognized religious minorities, who, within the limits of the law, are free to perform their religious rites and ceremonies, and to act according to their own canon in matters of personal 
affairs and religious education." ${ }^{66}$ All unnamed religious groups, such as Iran's 300,000 Baha' is, have no constitutional right to practice their religion. ${ }^{67}$ Moreover, the constitution accords "full respect" and "official status" only to followers of six specified schools of Islam. ${ }^{68}$ Reports indicate widespread harassment, discrimination, and state violence against unprotected religious minorities in Iran, ${ }^{69}$ while Muslims from other branches of Islam, including many Sunnis, face significant discrimination and marginalization in employment and political representation. ${ }^{70}$ Evidence suggests even the named minority groups face discriminatory treatment, reflecting the impacts of the constitution's clear privileging of a single belief system. These constitutional provisions limiting religious freedom are buttressed by laws criminalizing "enmity against God." ${ }^{11}$

An example of differential treatment of groups comes from Liechtenstein. While not explicitly limiting the right to practice to specific religious minorities, the constitution draws a distinction in rights between adherents of the state religion and members of other faiths: "The Roman Catholic Church is the State Church and as such enjoys the full protection of the State; other confessions shall be entitled to practise their creeds and to hold religious services to the extent consistent with morality and public order." 72 While Liechtenstein's provision may embody a lesser degree of repression, evidence suggests that the country's minority religions struggle for equality. For example, although 5.9\% of Liechtenstein's 39,00o residents are Muslims, there are no mosques in the country, and Muslims have faced difficulty in seeking to rent rooms for prayer. ${ }^{73}$

\section{Targeting Proselytism}

A few countries' constitutions ban proselytizing by specific religious groups. For example, Somalia's constitution proclaims: "No religion other than Islam can be propagated in the Federal Republic of Somalia." ${ }^{74}$ While blanket limits on coercive forms of proselytizing have been deemed justified by regional and international tribunals, ${ }^{75}$ selective limits that target only particular religions and ban noncoercive proselytizing are discriminatory.

\section{Exclusionary Provisions}

Finally, some constitutions include provisions that do not target religious practice as directly, but send a message of exclusion of particular religions (Table 2). For example, under Switzerland's constitution, freedom of belief is guaranteed, but "the construction of minarets [the mosque towers from which Muslims are called to prayer] is prohibited." ${ }^{76}$ This provision resulted from a 2009 referendum in which $57.5 \%$ of voters supported the amendment. At the time, there were only four minarets across the country. Responding to the vote, Farhad Afshar, director of the Coordination of Islamic Organizations in Switzerland, remarked: "Most painful for us is not the minaret ban, but the symbol sent by this vote. Muslims do not feel accepted as a religious community." ${ }^{77}$ 


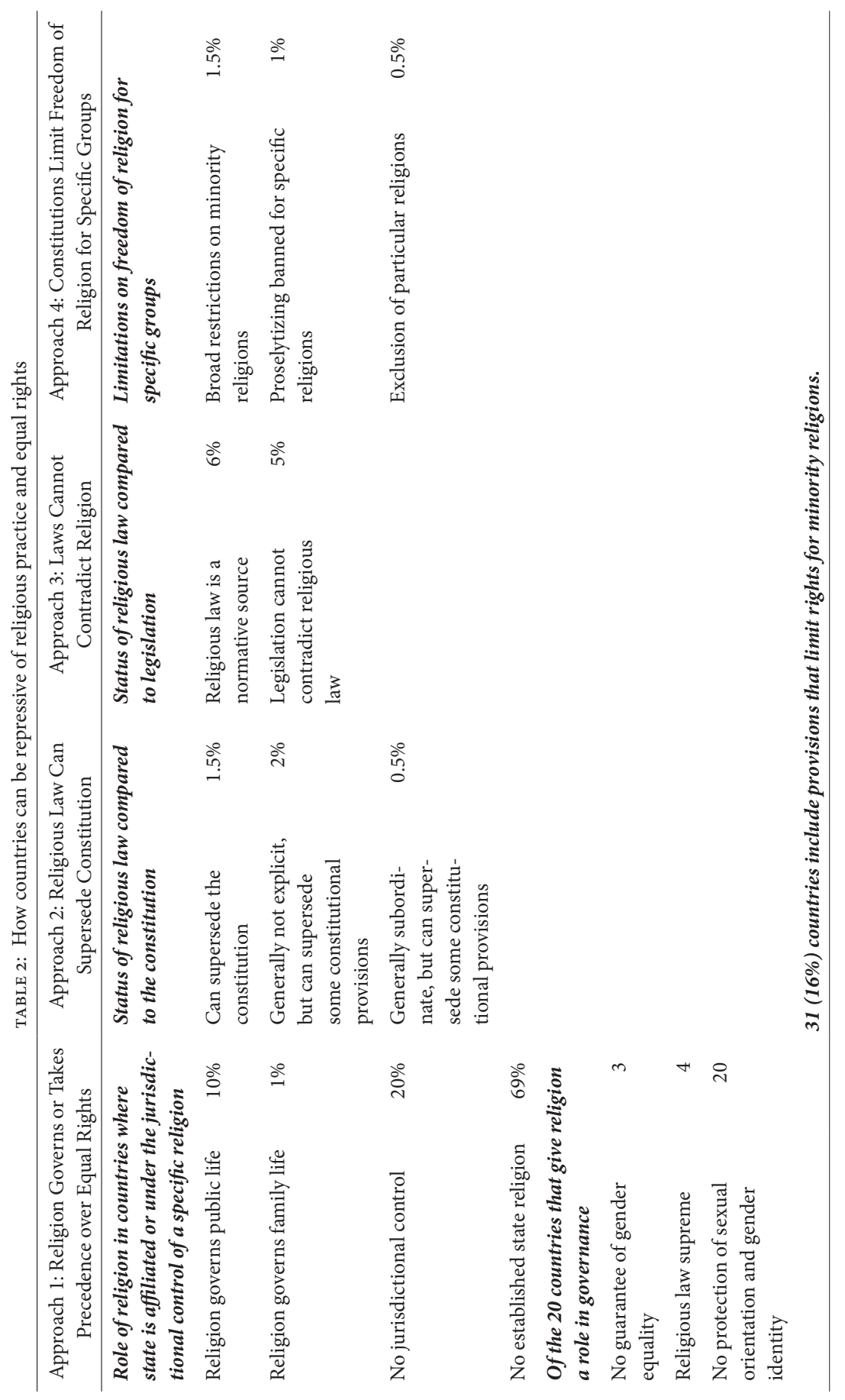


The Importance of Other Constitutional Protections in the Context of Religious Government

While giving one religion a role in governance inherently conflicts with full equality across religions and beliefs, other provisions within a constitution can nevertheless provide important and impactful safeguards for the equal rights of all. Specifically, protections for freedom of religion and comprehensive guarantees of nondiscrimination in countries with state religions can provide important foundations for ensuring the rights of religious minorities and challenging discrimination that affects other groups.

As explored in the preceding section, the establishment of a state religion doubtless creates a significant threat to freedom of religion. Moreover, the greater the role of a state religion as a source of both norms and law, the greater the likelihood that religious minorities will face barriers to observing their faiths, and that people without religious beliefs will face pressure to adhere to religious doctrine.

Still, even as full religious freedom may be unattainable in countries with a state religion, guarantees of freedom of religion remain essential in these contexts. International treaties uphold this view by clearly establishing that governments must protect religious minorities' rights and religious freedom regardless of the state-religion relationship. For example, as affirmed by the U.N. Human Rights Committee in a comment on the ICCPR: "The fact that a religion is recognized as a State religion or that it is established as official or traditional or that its followers comprise the majority of the population, shall not result in any impairment of the enjoyment of any of the rights under the Covenant, including articles 18 [freedom of religion] and 27 [rights of religious minorities], nor in any discrimination against adherents of other religions or non-believers." 78

Malaysia provides one example of these practical implications. Under Article 3 of Malaysia's constitution, "Islam is the religion of the Federation; but other religions may be practised in peace and harmony in any part of the Federation." 79 Article 11 further provides: "Every person has the right to profess and practise his religion." ${ }^{\circ \circ}$ According to census figures, 61\% of Malaysians identify as Muslims, while $20 \%$ are Buddhists and $9 \%$ are Christians. ${ }^{81}$

Malaysia is also one of a few countries that include religion on national ID cards. In 2015, Azmi Mohamad Azam Shah, who as an eight-year-old converted to Islam with his family, sought to renounce Islam, convert to Christianity, and change his name and religious affiliation on his ID card accordingly. Shah, who now goes by the name Roneey Anak Rebit, was told by the National Registration Department that he would need to bring a letter of release from Islam from the Syariah Court, which administers Islamic law. However, the Syariah Court refused to provide the letter, claiming lack of jurisdiction since Rebit was no longer a Muslim.

Rebit then challenged the National Registration Department's requirements within the civil legal system. Before the Kuching High Court, Rebit argued that 
he should be able to change his name and religion without the Syariah Court's approval, by nature of his constitutional right to freedom of religion. In a landmark 2016 decision, High Court judge Datuk Yew Jen Kie agreed, citing the constitution's protections in Article 11. She commented on the decision to the press: "He does not need a Syariah Court order to release him from Islam because freedom of religion is his constitutional right and only he can exercise that right." ${ }^{\prime 2}$ In November 2016, Rebit received his new ID card..$^{83}$

A range of religious groups welcomed the decision. The Association of Churches in Sarawak urged the government to "uphold the constitutional rights and fundamental liberties accorded by the federal constitution to all citizens of Malaysia," while Sisters in Islam noted approvingly that " $[t]$ his judgment reaffirms the supremacy of the Federal Constitution, which under Article 11 defends every Malaysian citizen's right to freedom of religion." ${ }^{84}$

Strong protections against discrimination on other grounds can also make a difference in countries with a state religion. One example comes from Tunisia.

In 2014, Tunisia adopted a new constitution, drafted by a constituent assembly that included both secular groups and members of the country's religious political party. The constitution establishes that Tunisia's "religion is Islam" and restricts eligibility for the presidency to Muslims (though not elevating religious law above the constitution); however, it also guarantees freedom of religion and creates strong protections for gender equality. Beyond explicitly committing to equal rights for men and women, the Tunisian Constitution "unequivocally affirms gender equality in the workplace, the right to adequate working conditions, and a fair wage for both sexes," and obliges the state to promote women's equal political representation and work toward eradicating violence against women..$^{85}$ Responding to input from civil society organizations, the final draft omitted earlier-proposed references to men and women as "complementary" rather than equal. ${ }^{86}$

Since its enactment, the constitution has provided a foundation for further change: in 2017, President Beji Caid Essebsi launched the Individual Freedoms and Equality Committee (COLIBE), tasked with ensuring consistency between Tunisia's laws and new constitution. ${ }^{87}$ Also in 2017 , citing the constitution's equal rights provision, Essebsi called for gender equality in the inheritance law and lifted a 44-year ban on Muslim Tunisian women marrying men from other religions, which had imposed no equivalent restrictions on Muslim men. ${ }^{88}$ More recently, COLIBE issued a report recommending gender equality in inheritance, the right to confer citizenship, and the right to pass on one's last name to children. ${ }^{89}$

\section{HOW CONSTITUTIONS CAN SET UNEQUAL NORMS}

The third broad group of constitutions includes those referenced throughout the preceding sections, which do not go so far as to make religion the source of 


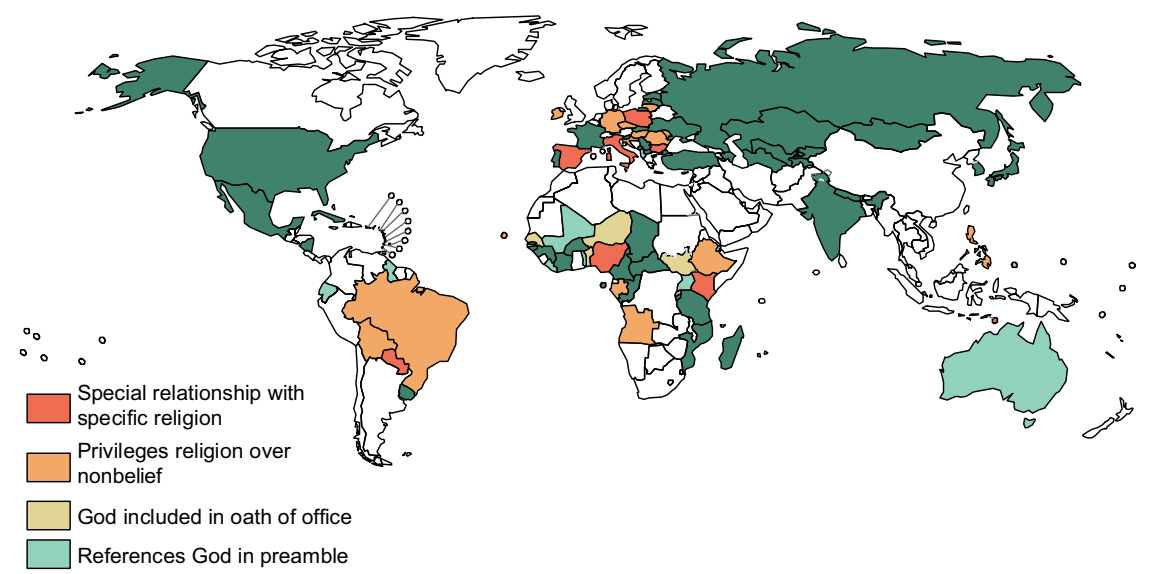

MAP 17. How do countries that identify in their constitution as secular treat religion?

law, but do give some special recognition to a particular religion or religious views. These types of provisions may be historical holdovers or recently negotiated compromises. However, especially in an era of increased migration and growing religious diversity, recognizing ways that constitutions subtly privilege a particular set of religious beliefs over others is important for identifying the full scope of barriers to equal treatment (Table 3). These provisions may affect not only the exercise of rights, but also the cultural norms shaping whether religious minorities are welcomed and accepted. Already, $27 \%$ of people live in countries where they are religious minorities, and this figure will likely increase in the coming decades..$^{\circ \circ}$

Altogether, $57 \%$ of constitutions include provisions communicating a preference for one religion over others, or for religion generally over nonbelief. In some of these countries, the constitution designates a "state religion" but does not endow that religion with legal authority, or acknowledges a history or special relationship with a specific religion. For example, the preamble of the Bahamas' constitution references "an abiding respect for Christian values and the Rule of Law." ${ }^{11}$

Self-identified secular countries also commonly include a role for religion. Indeed, only around half of the constitutions that establish state secularism or separation of religion and state fully reflect those very principles in their text (Map 17). In the remainder, the constitution outlines a special relationship with a specific religion, privileges religion over nonbelief, requires leaders to swear on God's name in the oath of office, or references God in the preamble. This also includes one country (Kenya) that provides for Islamic courts.

For example, Bulgaria's constitution states: "Religious institutions shall be separate from the state. . . Eastern Orthodox Christianity shall be considered the 


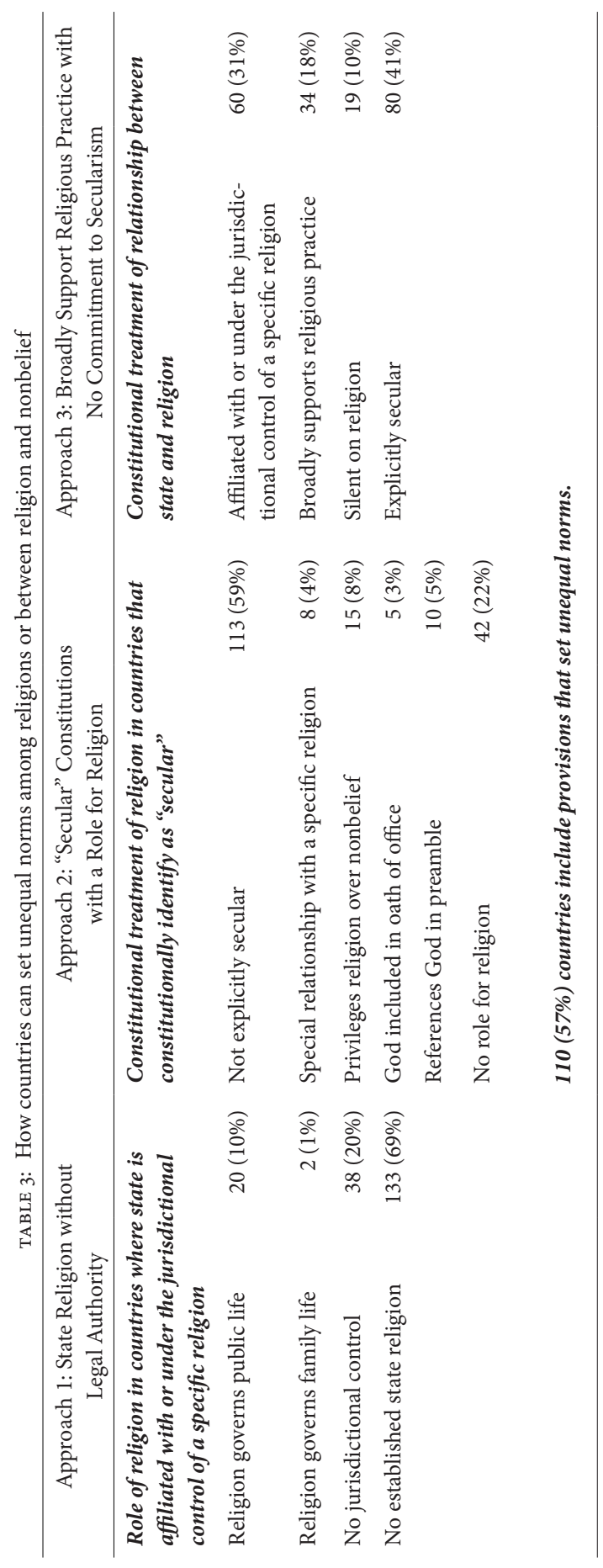


traditional religion in the Republic of Bulgaria." Croatia's constitution commits to supporting religious groups without specifying equal support for non-religious groups with similar goals:

All religious communities shall be equal before the law and clearly separate from the state.

Religious communities shall be free, in compliance with law, to publicly conduct religious services, open schools, academies or other institutions, and welfare and charitable organizations and to manage them, and they shall enjoy the protection and assistance of the state in their activities. ${ }^{92}$

Finally, $18 \%$ of constitutions include provisions or language that support religious practice, but do not specify a particular religion. In most cases, the preamble includes references to God and the constitution does not explicitly address the relationship between the state and religion. This includes one country (Switzerland) that leaves the question of separation between state and religion to subnational units.

\section{THE COMPLEXITY AND IMPORTANCE OF ADDRESSING RELIGION AROUND THE WORLD}

As this analysis reveals, few countries have constitutional provisions that comprehensively protect: (1) freedom of religion, belief, and nonbelief, with a safeguard for the rights of others; (2) nondiscrimination on the basis of religion or belief; and (3) the separation of religion and government. Many of the most significant constitutional restrictions on equality are found in the Middle East and North Africa, a region including 14 of the world's 20 countries with a state religion governing public and private life. Nonetheless, discriminatory restrictions on religious freedom cut across countries in Europe and elsewhere, including Switzerland and Liechtenstein.

Furthermore, while a substantial number of countries identify as "secular," this designation belies notable variation in national approaches. Nearly half of these countries include references to either a specific religion or God, which implicitly endorses monotheistic faiths. Consequently, even among constitutions that include commitments to secularism, many cannot assert "neutrality" on religion's role in society. Additionally, this variation in how countries define "secular" in the text is mirrored by variation in courts' application of the concept. ${ }^{93}$

As countries revise existing constitutions or draft new ones, their treatment of equal rights across religion and belief is an important area for continued review and advancement. While there are various constitutional approaches to protecting equality across religions, guaranteeing freedom of religion and the separation of religion and government are two foundational elements.

Further, there is ample reason to believe this approach works, if we measure effectiveness by the lack of religious discrimination and the presence of 
flourishing religious practice. A series of studies across the world's constitutions provide interesting insights into how religion provisions shape exclusionary practice and equality for people of all faiths and beliefs. They first examine countries' religious legislation, including whether they impose restrictions on interfaith marriages, fund religion or require religious education in schools, or have religious appointments to government offices. They then assess the relationship between constitutional provisions concerning religion and the existence of these types of religious laws.

In short, when constitutions guarantee freedom of religion, there is less religious discrimination by the government in the form of religious legislation. Similarly, when constitutions guarantee separation of religion and state or prohibit religious discrimination, countries are less likely to legally privilege or burden specific religions. ${ }^{94}$ Meanwhile, countries with an official religion are much likelier to have religious discrimination in the law. This is true overall. However, the countries where this most commonly occurs, likely because of the larger role given to religious law, are Muslim-majority countries. ${ }^{95}$

Most interestingly, religious practice flourishes in countries with more religious freedom. Both restrictions on religious freedom and state religions negatively impact the percent of the population that is regularly practicing their religion. Those countries that guarantee freedom of religion and have no state religion saw religious practice grow in the years following their constitutions' passage. ${ }^{96}$

\section{IMPLEMENTING RELIGIOUS FREEDOMS IN THE COURTS}

As explored previously, constitutional text can provide a starting point for guaranteeing that all people have an equal right to practice their religion, while ensuring that religious practices do not undermine others' fundamental rights. However, even compared to other complex topics explored in this book, freedom of religion presents unique challenges with respect to ensuring consistent rulings across courts. Courts are tasked with continually defining and redefining the line between freedom of religion and freedom from religion. Is allowing an Amish family to homeschool their 14-year-old child protecting their freedom of religionor infringing on the child's right to education? ${ }^{27}$ Can a private business choose to serve only those clients whose views and relationships align with the owner's religious beliefs? ${ }^{98}$ Does a statute prohibiting stores from selling goods on Sundays infringe business owners' religious freedom? ${ }^{99}$ Can someone be convicted for refusing military service based on their religious beliefs? ${ }^{100}$

These are among the many questions about religious freedom that have reached countries' highest courts. Yet although constitutional texts rarely provide crystal-clear answers to cases presenting nuanced sets of facts, two factors that may influence decision-making are the extent to which constitutions protect other 
fundamental rights, and whether constitutions clearly state that equal rights take precedence. Specifically, the strength of other equality provisions in a country's constitution-such as whether it unequivocally protects equal rights regardless of sexual orientation-may affect how courts interpret religious freedom in a given set of circumstances. Similarly, the strength of protections of other groups' equal rights, including those of women, can influence how judges rule when religious practices conflict with equality.

These relationships among rights are explored further below, through cases from the United States and South Africa. As emphasized throughout this chapter, international law is clear that the exercise of religion, while an important freedom, should not infringe on others' rights. Yet to fully understand this principle's implications - and identify strategies to support its realization-it is important to examine some common manifestations of this conflict in practice. At the national level, there are two common and significant ways religion can threaten others' fundamental equal rights: first, through the invocation of freedom of religion as a justification to discriminate, including by private businesses and employers; and, second, through constitutions that allow religious law to supersede equal rights provisions.

\section{Freedom of Religion, not Freedom to Discriminate}

As previously noted, nearly half of countries (46\%) explicitly acknowledge that some restrictions may be placed on religious conduct to protect people's fundamental rights and freedoms; other countries apply similar analyses through the courts. However, the extent to which equal rights take precedence over religiously motivated discrimination often hinges on several factors and aspects of the country's constitutional system. These include whether the discrimination occurred in a public or private setting, who engaged in discrimination, and whether the constitution explicitly protects against discrimination for the affected group.

In recent years, this tension has emerged with respect to sexual orientation in a number of countries. A range of courts have evaluated constitutional challenges involving businesses or service providers that decline to serve lesbian or gay clients, arguing that doing so would conflict with their religious freedom. An example from the United States highlights the impact of lacking clear constitutional protections for marginalized groups and shifting norms on how courts negotiate the balance between religious freedom and equal rights.

In Colorado, an antidiscrimination law prohibited businesses serving the public from discriminating on the basis of sexual orientation. However, citing his Christian beliefs, a bakery owner refused to make a cake for a same-sex couple's wedding. According to the baker, being compelled to make the cake would require him to express support for gay marriage, violating his First Amendment rights of freedom of religion and expression. 
In 2018, the Supreme Court ruled 7-2 in favor of the baker in Masterpiece Cakeshop v. Colorado Civil Rights Commission. ${ }^{101}$ The legal basis of the decision was narrow: rather than establishing a new constitutional precedent on freedom of religion versus equal rights, the Court's decision rested on its finding that the Colorado Civil Rights Commission, which had ruled against the baker after the couple filed a complaint, had not acted with "religious neutrality" in assessing the baker's objections.

Perhaps more remarkable, however, was the amicus brief submitted by the U.S. Department of Justice (DOJ), which underscored how explicit protections against discrimination in constitutional texts and jurisprudence may influence whether freedom of religion takes precedence over equal rights. In urging the Court to decide in favor of the baker, the DOJ drew a distinction between discrimination by businesses based on race and discrimination based on sexual orientation. The brief argued that racial discrimination carries greater weight against the First Amendment than sexual orientation discrimination, partly because racial discrimination is subject to "strict scrutiny" constitutional review while sexual orientation discrimination is not. The government further claimed that private racial discrimination "violates deeply and widely accepted views of elementary justice," whereas "opposition to same-sex marriage has 'long been held-and continues to be held-in good faith by reasonable and sincere people." ${ }_{102}$ In other words, the government's top lawyers invoked both inadequate protections in constitutional law and discriminatory social norms to justify continued discrimination against same-sex couples.

This argument aligns with past cases that have excused sexual orientation discrimination on the basis of First Amendment rights, but have not accepted the same rationale for racial discrimination. ${ }^{103}$ Given these precedents, it seems reasonable to infer that the stronger the Court's rulings have been historically against a particular type of discrimination, the likelier it is the Court will find that equal rights prevail over religiously motivated exclusion. Constitutionally speaking, LGBT + rights are a relatively new topic, at least in comparison to racial discrimination-and as the DOJ itself noted, there remains less nationwide consensus about full equality. It is for this reason that explicit protections against discrimination on the basis of sexual orientation and gender identity (SOGI), as discussed in chapter 6, are so essential.

\section{Pluralistic Legal Systems}

Pluralistic legal systems are those that recognize the authority of more than one type of law. ${ }^{104}$ Two major types of pluralistic legal systems are those recognizing customary law, and those recognizing religious law. Some countries fall within both categories. Generally, however, most countries that recognize customary law are former British and French colonies in Africa and Asia; ${ }^{105}$ in many of these countries, customary law was unwritten before colonialism, but certain aspects became codified by colonial officials, who often consulted with just a 
small number of male elders. ${ }^{106}$ Nearly all countries that recognize religious law are Muslim-majority. ${ }^{107}$

As discussed earlier, international law indicates that any pluralistic system should still honor fundamental human rights. There is no reason to believe that countries cannot guarantee equality while simultaneously enabling the full exercise of religious freedoms. In 2017, a group of religious leaders from around the world, representing various faiths, convened to issue a declaration affirming their "deep conviction that our respective religions and beliefs share a common commitment to upholding the dignity and the equal worth of all human beings," which included references to all the foundational religious texts. ${ }^{108}$ Among the declaration's 18 commitments are pledges to "promote constructive engagement on the understanding of religious texts," "ensure non-discrimination and gender equality," "stand up for the rights of all persons belonging to minorities," and "monitor interpretations, determinations or other religious views that manifestly conflict with universal human rights norms and standards." ${ }^{109}$

Approaches vary among countries with constitutionally established pluralistic systems. In two such countries, South Africa and Cyprus, religious law is explicitly subordinate to the constitution. South Africa's constitution provides that legislation may recognize "marriages concluded under any tradition, or a system of religious, personal or family law [and] systems of personal and family law under any tradition, or adhered to by persons professing a particular religion," but that this recognition "must be consistent with . . . the Constitution." ${ }^{110}$ In Cyprus, family law is "subject to the provisions of this Constitution." 111 However, in 13\% of countries, religious laws can take precedence over the constitution and/or laws cannot be enacted if they conflict with religious law or norms, placing equality and other fundamental rights at risk.

A significant case from South Africa's Constitutional Court illustrates the effect of language guaranteeing that constitutional equal rights take precedence. When Juleiga Daniels's husband Mogamat died in 1994, the couple had been sharing a small home in a Cape Town suburb for 17 years. ${ }^{112}$ Juleiga had lived there even longer, having shared the home with her first husband beginning in 1969. When Mogamat died without a will, a judicial officer was appointed to administer his estate. ${ }^{113}$ However, noting that her marriage had been conducted under Muslim rites, the officer told Juleiga she had no entitlement to the property. ${ }^{114}$

Because Juleiga and Mogamat had been married under Islamic law, their union was not formally recognized by the state. Therefore, Juleiga was not covered by the legal benefits and protections established by the country's Marriage Act. Consequently, after Mogamat's death, Juleiga suddenly found herself facing eviction, completely excluded from the inheritance rights typically guaranteed to South African wives.

Juleiga's loss of her property rights resulted from how the law treated both her religion and her gender. When Juleiga and Mogamat married in 1977, they 
provided a copy of their marriage certificate to the city, which then transferred the tenancy of Juleiga's home to Mogamat, considering him the "principal breadwinner." In 1990, Mogamat entered into an agreement with the property owner to purchase the home. Although Juleiga contributed to the purchase price and co-signed the deed of sale, after Mogamat died, the property was transferred to his estate-and Juleiga was told she had no claim to it since she was not legally his "surviving spouse."

Juleiga decided to challenge this interpretation, arguing that her exclusion from the laws on inheritance and maintenance was discriminatory on the basis of gender, religion, and marital status. In 2003, her case reached the Constitutional Court, where Justice Albie Sachs walked through a careful analysis of the facts and the applicable law. Justice Sachs first examined the plain meaning of the term "spouse," finding: “The word 'spouse' in its ordinary meaning includes parties to a Muslim marriage. ... It is far more awkward from a linguistic point of view to exclude parties to a Muslim marriage from the word 'spouse' than to include them. ... Such interpretation owed more to the artifice of prejudice than to the dictates of the English language."115

Justice Sachs then turned to the intent of both the law and the constitution. He noted that the constitution aims to achieve "substantive equality between men and women," although "[t]he reality has been and still in large measure continues to be that in our patriarchal culture men find it easier than women to receive income and acquire property." ${ }^{\prime 16}$ Regarding the laws on inheritance and maintenance, Justice Sachs proclaimed: "The central question is not whether the applicant was lawfully married to the deceased, but whether the protection which the Acts intended widows to enjoy should be withheld from relationships such as hers." Using this analytical frame, the Court found that the term "spouse" must be interpreted to include a "party to a monogamous Muslim marriage." Juleiga, whose marriage to Mogamat was always monogamous, was thus entitled to stay in her home. ${ }^{17}$

In so doing, the Court affirmed that the constitution's protection of equal rights took precedence over conflicting religious laws. As a concurring opinion from Justice Dikgang Moseneke observed, "[ $\mathrm{t}]$ he tenets of our Constitution promises religious voluntarism, diversity and independence within the context of the supremacy of the Constitution." ${ }^{118}$ Further, the decision made clear that under the constitution's clearly articulated guarantee of gender equality, Muslim women share the same inheritance rights as women who marry according to other religious traditions.

\section{CONCLUSION: ACHIEVING THE BALANCE}

Guarantees of the right to freedom of religion, broadly defined, are nearly universal across constitutions adopted in the past 60 years, and protections against 
religious discrimination have steadily increased. Yet to truly understand religious freedom and equality in a given country, we cannot consider this language alone. Many countries that guarantee freedom of religion also privilege one religion in governance, effectively undermining full equality across religions, beliefs, and nonbeliefs. Likewise, even if they do not specify that religion governs public or private life, a range of countries' constitutions more subtly support one religion over others, potentially impeding the development of norms embracing the full inclusion of all.

Similarly, even countries that identify as "secular" take a range of approaches to religion that do not always treat all religions or beliefs equally. Some of this variation is evident in the constitutional text; other points of divergence emerge in how courts interpret secularism. This complexity illustrates how taking a "neutral" stance to religion-one that is "truly areligious and that neither favors nor disadvantages any religion or the non-religious" ${ }^{\prime 19}$ - is a challenge on its own, and the meaning of "neutrality" will likely remain contentious as religious demographics continue to shift with large-scale migration.

Nevertheless, the principles initially established in international law can provide a valuable framework for resolving even complex cases, and should provide a foundation for further constitutional reform. Global agreements are clear that states cannot discriminate on the basis of religion, nor can religion be invoked as a basis for discrimination on other grounds. Moreover, while freedom of religion is central, so too is the freedom to denounce, change, or forego religion entirely, and international law recognizes that these are fundamentally personal choices. To promote equality, constitution drafters and courts must continue returning to and actively advancing these principles. Further, strengthening other rights in constitutions-such as rights to health, education, substantive gender equality, and nondiscrimination on the basis of SOGI-would provide a stronger constitutional basis for ensuring that freedom of religion does not take precedence over equal rights. 